\title{
Construction of green fluorescent protein based bacterial biosensor for heavy metal remediation
}

\author{
C. Edward Raja; *G. S. Selvam \\ Department of Biochemistry, School of Biological Sciences, Center for Excellence in Genomic Sciences, \\ Madurai Kamaraj University, Madurai 625021, India
}

Received 16 July 2010; revised 1 November 2010; accepted 5 August 2011

\begin{abstract}
ABS TRACT: Environmental contamination by heavy metals is a worldwide problem. Therefore, it is necessary to develop sensitive, effective and inexpensive methods, which can efficiently monitor and determine the level of hazardous metals in the environment. Conventional techniques to analyze metals, suffer from the disadvantages of high cost. Alternatively, development of simple system for monitoring heavy metals pollution is therefore needed. The present approach is based on the use of bacteria that are genetically engineered so that a measurable signal is produced when the bacteria are in contact with the bioavailable metal ions. Reporter genes are widely used as genetic tools for quantification and detection of specific cell population, gene expression and constructing whole cell biosensors as specific and sensitive devices for measuring biologically relevant concentrations of pollutants. An attempt has been made to construct the reporter gene enhanced green fluorescent protein and was expressed under the control of cadR gene, responsible for cadmium resistance. Recombinant strain Escherichia coli cadR30 was used, that carried cadR gene in pET30b expression vector and cloned. Clones confirmed by the expression of enhanced green fluorescent protein was detected under ultraviolet illumination and separated on sodium dodecyl sulfate polyacrylamide gel electrophoresis. The construction of green fluorescent protein based Escherichia coli bacterial biosensor was developed based on green fluorescent protein expression under the control cadR gene of Pseudomonas aeruginosa BC15. The constructed bacterial biosensor is useful and applicable in determining the availability of heavy metals in soil and wastewater.
\end{abstract}

Keywords: Aquatic environment; Contamination; E.coli; Pseudomonas aeruginosa; Reporter gene

\section{INTRODUCTION}

The pollution of the environment with toxic heavy metals is spreading through the world along with industrial progress. Cadmium $(\mathrm{Cd})$, lead $(\mathrm{Pb})$ and other heavy metals are of considerable interest due to their toxicity and extensive application in the industry (Gueu et al., 2007; Karbassi et al., 2008). Therefore, it is necessary to develop sensitive, effective and inexpensive methods which can efficiently monitor and determine the presence and amount of hazardous metals in the environment. Traditionally, the environmental risk caused by heavy metals pollution is determined by quantification of total metals after digestion with strong acids by using conventional analytical methods (Liao et al., 2006). Conventional techniques to analyze metals include chemical precipitation, ion exchange, chelation, membrane separation (Samarghandi et al., 2007; Malakootian et al., 2009) and cold vapour atomic adsorption spectrometry, inductively coupled plasma

*Corresponding Author Email: drselvamgsbiochem@rediffmail.com Tel.:+914522459123; Fax: +91452 2459181 mass spectrometry, UV visible spectrometry and X-ray absorption spectroscopy (APHA, 1992; Townsend, 1998). These techniques are highly precise, though suffering from disadvantages of high costs (Mulchandani and Bassi, 1995; D’Souza, 2001). Therefore, development of a simple alternate system for monitoring heavy metals by microorganisms, due to its potential applications in environmental protection and toxic heavy metals recovery, is essential (Andreazza et al., 2010). Biosensor is an analytical device that consists of immobilized biological material in intimate contact with a compatible transducer, which will convert the biochemical signal into a quantifiable electrical signal (Gronow, 1984; Chien and Shih, 2007). The biosensors rely on analysis of gene expression typically by creating transcriptional fusions between a promoter of interest and the reporter gene expression serves as a measure of the availability of specific pollutants in complex environments (Liu et al., 2004; Nouri et al., 2009; 2011). The major attributes of a good biosensing system are 
its specificity, reliability, ability to function in optically opaque solution, real-time analysis and simplicity of operation (D'Souza, 2001). Bacterial biosensors are microorganisms engineered to detect target chemical compounds or changes in physico chemical conditions through inducible expression of reporter protein (Vandeer meer, 2004). Several metal specific bacterial sensors for the detection of bioavailable metals were developed with fusing metal regulatory protein gene with various reporter genes by many authors (Selifonova et al., 1993; Tauriainen et al., 1998; Ivask et al., 2001). Bacterial biosensors for $\mathrm{Cd}$ and $\mathrm{Pb}$ have been previously described utilizing reporter genes such as $l a c Z, l u x$ and $l u c$ in the transcription fusion constructs (Tauriainen et al., 1998; Shetty et al., 2003). Green fluorescent protein (GFP) is an auto illuminating protein isolated from the jellyfish Aequorea victoria (Chalfie et al., 1994) is increasingly being used as a reporter gene. GFP is the reporter whose autofluorescence can be produced without the addition of an exogenous substrate or adenosinetriphosphate (ATP) (Stiner et al., 2002). GFP has been used extensively to measure gene expression in identified transplanted cells and analyze differentiation processes in mammalian systems (Yagi, 2007). In the present study, an attempt was made to construct GFP-based bacterial biosensor E. coli expressed under the control of $c a d R$ gene of Pseudomonas aeruginosa BC15. This research was carried out from January to June 2008 at the Department of Biochemistry, School of Biological Sciences, Madurai Kamaraj University, Madurai, South India.

\section{MATERIALS AND METHODS}

The source and growth conditions of the strains were used in the study is mentioned in Table 1. Plasmid DNA from bacterial strains was isolated by alkaline lysis method. The plasmid DNA was used to transform Escherichia coli (E. coli) BL21 by calcium chloride transformation method. The plasmid DNA isolation, transformation procedure adopted was as described by Sambrook et al. (1989). The vector map of pEGFP-1 is shown in Fig. 1. It is a selectable vector for monitoring promoter activity in mammalian cells via fluorescence of a GFP derivative. The vector backbone contains pUCderived ori for propagation in E. coli.

The plasmid DNA pEGFP-1 was isolated and digested with BamHI / NotI and resulting fragment EGFP was reintroduced into BamHI / NotI digested pET30b and then transformed to E. coli BL21. Transformants were selected on Luria-Bertani (LB) agar plates containing
Table 1: Bacterial strains and plasmids used in this study

\begin{tabular}{|c|c|c|}
\hline $\begin{array}{l}\text { Strain / } \\
\text { plasmid }\end{array}$ & $\begin{array}{l}\text { Relevant phenotype } \\
\text { / genotype }\end{array}$ & $\begin{array}{l}\text { Source/ } \\
\text { reference }\end{array}$ \\
\hline $\begin{array}{l}\text { Pseudomonas } \\
\text { aeruginosa } \\
\text { strain } \mathrm{BC} 15\end{array}$ & Heavy metal resistance & $\begin{array}{l}\text { Edward Raja } \\
\text { and Selvam, } \\
2009\end{array}$ \\
\hline E. coli $\mathrm{DH} 5 \alpha$ & $\begin{array}{l}\text { supE44lacU169(Ф801acZM15) } \\
\text { hsdR17recA1endA1gyrA96thi- } \\
\text { 1relA }\end{array}$ & $\begin{array}{l}\text { Invitrogen } \\
\text { (CA,USA) }\end{array}$ \\
\hline BL21(DE3) & hsdS gal $(\lambda$ cIts857ind 1 & \\
\hline pET30b & Sam7 nin5lacUV5-T7gene1) & $\begin{array}{l}\text { Novagen } \\
\text { (CA,USA) }\end{array}$ \\
\hline $\begin{array}{l}\text { E. coli } \\
\text { cadR30 }\end{array}$ & $\begin{array}{l}\text { Expression vector } \\
\text { E. coli carrying cadR }\end{array}$ & $\begin{array}{l}\text { Novagen } \\
\text { (CA,USA) }\end{array}$ \\
\hline & & $\begin{array}{l}\text { P. aeruginosa } \\
\mathrm{BC} 15\end{array}$ \\
\hline
\end{tabular}

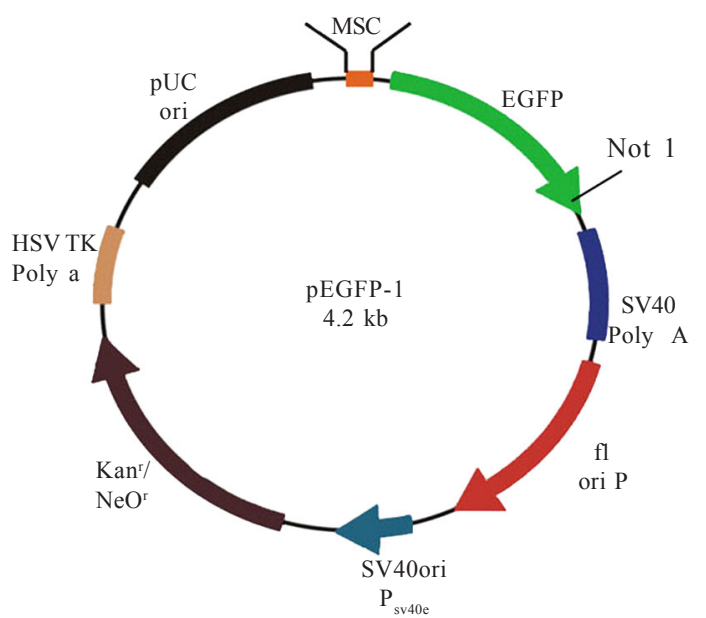

Fig. 1: Vector map of pEGFP-1

kanamycin $(30 \mu \mathrm{g} / \mathrm{mL})$ and IPTG $(40 \mathrm{mg} / \mathrm{mL})$. Cultures of E. coli $\mathrm{BL} 21$ (DE3) cells carrying E. coli $\mathrm{EGFP} 4$ was grown overnight in LB medium supplemented with $30 \mu \mathrm{g} / \mathrm{mL}$ of kanamycin. After $12 \mathrm{~h}, 1 \%$ inoculum was sub cultured in fresh $\mathrm{LB}$ medium and incubated at $37^{\circ} \mathrm{C}$ with vigorous shaking. When the culture reached 0.7 Optical density (OD), the cells were induced with $40 \mathrm{mg} / \mathrm{mL}$ Isopropyl $\beta$ D-1-thiogalactopyranoside (IPTG) and growth was continued for $5 \mathrm{~h}$. Cells were harvested by centrifugation for $10 \mathrm{~min}$ at $12,000 \mathrm{rpm}$ at $4{ }^{\circ} \mathrm{C}$ and pellet was suspended in $2 \mathrm{x}$ Sodium dodecyl sulfate polyacrylamide gel electrophoresis (SDS-PAGE) lysis buffer. It was then heated in a water bath at $95^{\circ} \mathrm{C}$ for $2 \mathrm{~min}$. The lysate were harvested by centrifugation for $20 \mathrm{~min}$ at $10,000 \mathrm{rpm}$. The protein samples were analyzed in SDS-PAGE by the method of Laemmli (1970).

The $c a d R$ gene was amplified by using specific 
primers $C a d R$ F (5'-CGATGGGAT CCGGAGGGTT GGCATGAAGATCGG-3') and CadR R (5'CGGAATTCCTATGCACGAACTGGTCGCGC-3')which contains Bam $\mathrm{HI}$ and $E c o \mathrm{RI}$ restriction sites respectively. A Polymerase chain reaction (PCR) was performed with a $50 \mu \mathrm{L}$ reaction mixture containing $10 \mathrm{ng}$ of DNA extract as the template with each primer at a concentration of $0.5 \mathrm{mM}, 1.5 \mathrm{mM}$ Magnesium chloride $\left(\mathrm{MgCl}_{2}\right)$ and each Deoxynucleoside triphosphates (dNTPs) at a concentration of $50 \mathrm{mM}$, as well as 1units of Taq polymerase. After the initial denaturation for $5 \mathrm{~min}$ at $94{ }^{\circ} \mathrm{C}$, denaturation at $94^{\circ} \mathrm{C}$ for $1 \mathrm{~min}$, annealing at $65^{\circ} \mathrm{C}$ for $1 \mathrm{~min}$, extension at $72^{\circ} \mathrm{C}$ for $30 \mathrm{sec}$ for 2 cycles, then next two cycles denaturation at $94^{\circ} \mathrm{C}$ for $1 \mathrm{~min}$, annealing at $63{ }^{\circ} \mathrm{C}$ for $1 \mathrm{~min}$ and extension at $72{ }^{\circ} \mathrm{C}$ for $30 \mathrm{sec}$, finally 31 cycles carried out denaturation at $94^{\circ} \mathrm{C}$, annealing at $61{ }^{\circ} \mathrm{C}$ for $1 \mathrm{~min}$, and extension at $72{ }^{\circ} \mathrm{C}$ for 30 $\mathrm{sec}$ and then a final extension step consisting of $5 \mathrm{~min}$ at $72^{\circ} \mathrm{C}$. PCR was carried out in a Gene AMP PCR system 2700 . PCR products were analyzed in $1.5 \%$ agarose gel electrophoresis. The plasmid E. colicadR30 containing $c a d R$ gene was amplified by PCR reaction. The amplified product was digested with $B a m \mathrm{HI}$ and EcoRI and then reintroduced into $B a m \mathrm{HI}$ and $E c o$ RI digested $E$. coliEGFP4. After ligation, recombinants were transformed into E. coli BL21. The colonies were selected on LB agar plates supplemented with appropriate antibiotics.

\section{RESULTS AND DISCUSSION}

The GFP was obtained from the jellyfish Aequorea Victoria, and GFP gene was transferred, expressed in a wide range of organisms like mammals (Ludin et al., 1996), fishes (Moss et al., 1996), insects (Wang and Hazelrigg, 1994), plants (Casper and Holt, 1996), yeasts (Niedenthal et al., 1996) and a broad variety of bacteria (Chalfi et al., 1994). GFP has become a popular reporter for gene activity in bacteria. Therefore, it is generally being used either to establish the conditional expression of a gene in response to a specific substance, growth condition, or habitat (Barker et al., 1998; Shetty et al., 1999). The heavy metals such as $\mathrm{Cd}, \mathrm{Pb}$, nickel $(\mathrm{Ni})$, zinc ( $\mathrm{Zn}$ ) and chromium $(\mathrm{Cr})$ represent a serious problem to the environment and public health when they contaminate superficial and ground water (Barros et al., 2008). Cd is extremely toxic even in low concentrations, which tend to bioaccumulate in organisms and ecosystems (Kopera et al., 2004; Giaginis et al., 2006). Inhaling cadmium loaded dust quickly leads to respiratory tract, kidney problems and ingestion of any significant amount of cadmium causes immediate poisoning and inducing the damage to liver and kidney (Il'yasova and Schwartz, 2005). Whole cell biosensors utilizing microorganisms tackle and overcome several concerns raised with other conventional methods, because they are usually cheap, simple nature and easy to maintain while offering a sensitive response to the toxicity of a sample (Gu et al., 2004). In the present study, GFP was isolated from mammalian expression vector EGFP-1 and identified plasmid size was 4.2 kilo base pairs (kb) (Fig. 2a). The plasmid pEGFP-1 was digested with BamHI / NotI and then 800 base pairs (bp) released fragment EGFP (Fig. 2b) was reintroduced into Bam HI / Not I digest pET30b expression vector (Fig. 2c). The resulting recombinants were used to transform $E$. coli BL21. The colonies were selected based on the expression of EGFP with IPTG induction. Initially the EGFP was detected under Ultraviolet (UV) illumination and region of insert EGFP was confirmed through restriction analysis (Fig. 2d). E. coli expressing GFP a)

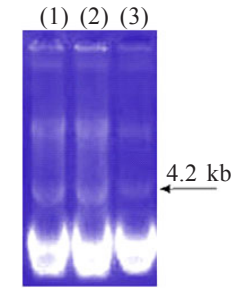

c)

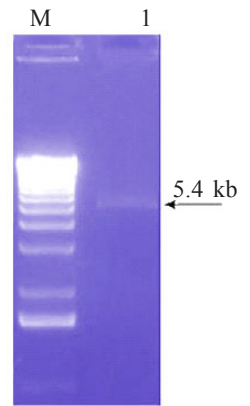

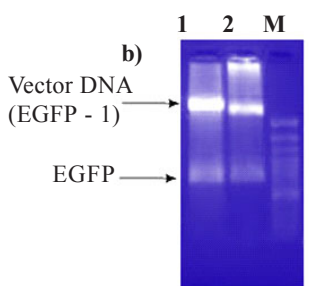

d)

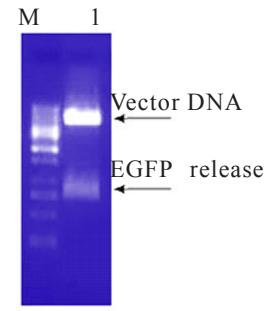

Fig. 2: (a) Isolation of EGFP-1 plasmid DNA by alkaline lysis method. Lanes 1, 2 and 3-= Plasmid DNA EGFP-1. (b) Restriction digestion of EGFP from mammalian vector. Lanes 1, 2= EFGP and vector and Lane M= Marker. (c) Restriction digestion of pET30b. Lane $M=1 \mathrm{~kb}$ DNA ladder; Lane $1=$ restricted fragment of pET30b. (d) Restriction digestion of plasmid pETEGFP4. Lane $\mathrm{M}=1 \mathrm{~kb}$ DNA ladder and Lane 1= Insert EGFP 


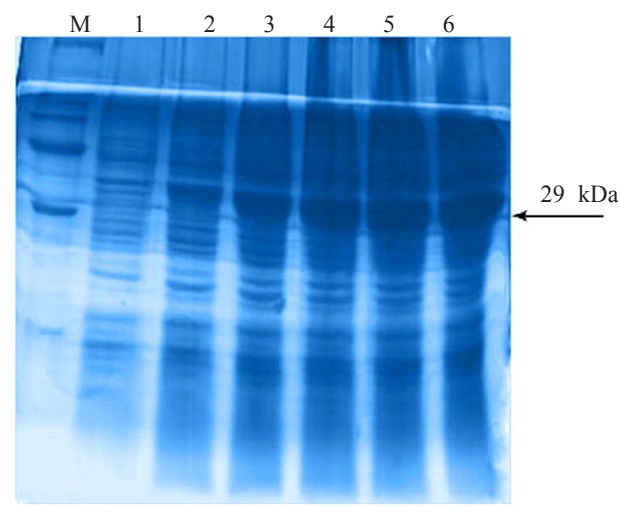

Fig. 3: Expression of GFP in E. coli. Lane M= Protein marker; Lane 1= Control (Without IPTG induction); Lanes 2, 3, 4, 5 and $6=$ Expressed GFPs in different hours

was grown in LB medium. After harvest, bacteria harbouring E. coliEGFP4 exhibited a substantial fluorescence.

The integrity of the recombinant GFP was analyzed on SDS-PAGE (Fig. 3). The estimated molecular weight of enhanced GFP was 29 kilo Dalton (kDa), which is in agreement with the calculated theoretical weight of $29.484 \mathrm{kDa}$ for native GFP. Similar observation has been reported earlier (Prachayasittikul et al., 2001). Generally reporter genes are widely used as genetic tools for quantification and detection of specific cell population, gene expression and root colonisation in complex samples (Cassidy et al., 2000). Novel areas for applying reporter genes in constructing whole cell biosensors as specific and sensitive devices for measuring biologically relevant concentrations of pollutants (Willardson et al., 1998). GFP has been successfully used as reporter within bacterial and yeast hosts due to the ease of in situ detection and the minimal metabolic cost of host cells (Roberto et al., 2002). In sensor bacteria, expression of a reporter gene is controlled by a metal responsive regulatory element, which usually originates from bacteria that are naturally resistant to a particular heavy metal. The regulatory element can be coupled to a reporter gene through a gene fusion that upon expression produces a readily measurable signal in response to a particular metal. Thus in the presence of particular heavy metals, the amount of reporter protein inside the cell increases. Hence, the amount of given metal was detected by measuring the reported protein produced by the sensor bacteria (Liao et al., 2006).

The plasmid DNA was isolated from E. colicadR30 by alkaline lysis method. The plasmid E. colicadR30 containing $c a d R$ gene (528 bp) was amplified and confirmed in $1.5 \%$ agarose gel electrophoresis (Fig. 4). Recombinant plasmids were constructed from $\mathrm{Bam} \mathrm{HI} /$ NotI digested E. coli EGFP4 and BamHI / NotI cut cadR region carrying plasmid $E$. coli cadR 30 . The construction of bacterial biosensor is shown in Fig. 5a. Out of 200 transformants, four colonies were selected based on the expression of GFP. The selected colonies were designated as E.coli cadREGFP4, cadREGFP14, cadREGFP29 and cadREGFP36. The biosensor plasmids adopted with EGFP were detected initially under UV illumination (Fig. $5 \mathrm{~b}$ ) and presence of $c a d R$ region was confirmed by PCR reaction (Fig. 5c). GFP-based E. coli cadREGFP14 was developed based on the GFP expression under the control of $c a d R$ gene of $P$. aeruginosa $\mathrm{BC} 15$ to be applicable for heavy metal bioremediation. In the same manner, GFP-based biosensor was developed from Staphylococcus aureus plasmid p1258 (Liao et al., 2006). A sensor plasmid was constructed by inserting the regulation unit from the cadA determinant of plasmid pI258 to control the expression of firefly luciferase. The sensor plasmid pTOO24 was capable of replicating in Gram negative bacteria. The expression of the reporter gene as a function of added extracellular heavy metals was studied in Staphylococcus aureus strain RN4220 and Bacillus subtilis strain BR151. The developed sensor strains RN4220 (pTOO24) and BR 151(pT0024) mainly respond to cadmium, lead and antimony, respectively (Tauriainen et al., 1998). The bacterial biosensor that responds to $\mathrm{Pb}$ by expressing GFP was constructed by the genetic element that senses $\mathrm{Pb}$ includes the regulatory protein gene $(\mathrm{PbrR})$ along with operator / promoter $(\mathrm{PbrO} / \mathrm{P})$

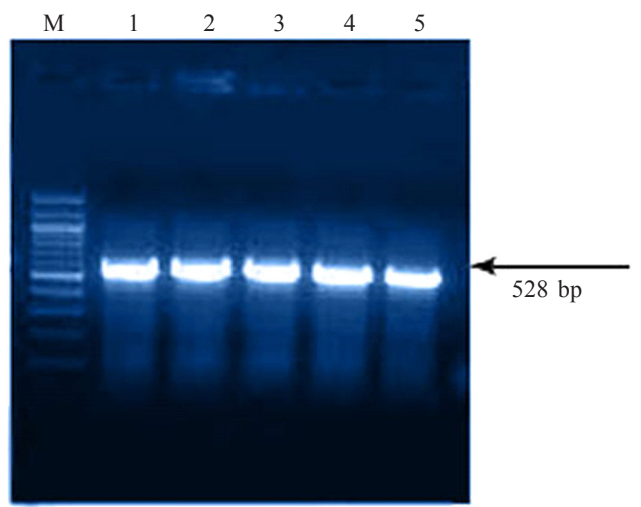

Fig. 4: Amplification of $c a d R$. Lane $\mathrm{M}=100 \mathrm{bp}$ ladder and Lanes 1, 2, 3, 4, and 5= PCR products. 

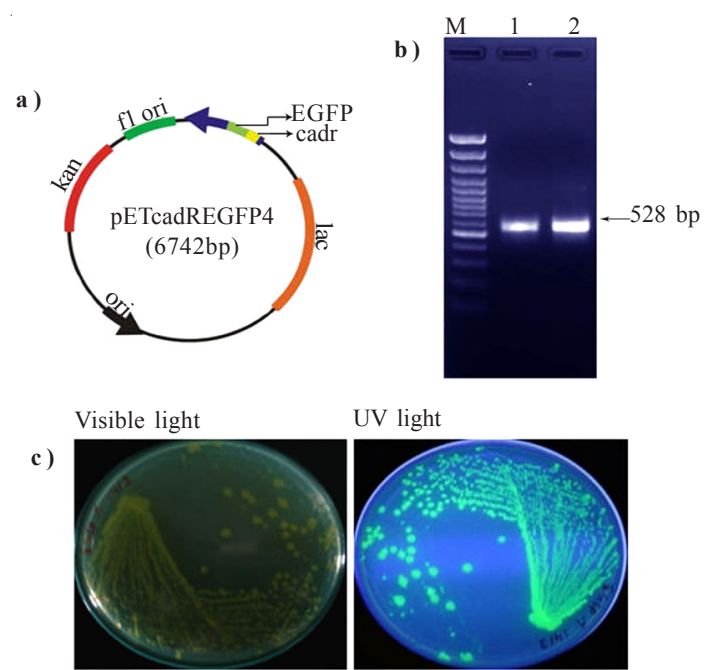

Fig. 5: (a) Cloning and construction of biosensor plasmid. (b) Amplification of cadR in E. coli cadR30EGFP4 by PCR reaction. Lane $M=100 \mathrm{bp}$ ladder and Lanes 1 and $2=$ PCR amplified products. (c) EGFP expression in biosensor plasmid under visible and UV light

of the $\mathrm{Pb}$ resistance operon from plasmid pMOL30 (Chakraborty et al., 2008). The present results demonstrate that the EGFP could successfully be used as a biosensor to determine the bioavailability of heavy metals in contaminated sediment, soil and wastewater.

\section{CONCLUSION}

The biosensor assays are sensitive, fast, inexpensive and less laborious, thus ideal for screening the presence of heavy metals in contaminated environment. The bacterial hosts incorporating the GFP-based sensor have proven to be a rapid and sensitive reporter system for the detection and monitoring of pollutants in environmental samples in developed countries. Therefore, the development of prokaryotic biosensors for local application would, in addition, also provide a cost-effective method of detecting environmental pollutants. The future aspect of the study is to develop GFP-based assays that would be appropriate and cost effective for environmental applications, to compare the GFP-based assay with standard water testing methods, and to develop local skills in GFP-based assays.

\section{ACKNOWLEDGEMENTS}

The authors would like to thank the University Grants Commission (UGC) for providing the Meritorious Fellowship for Bio-Sciences.

\section{REFERENCES}

Andreazza, R.; Pieniz, S.; Wolf, L.; Lee, M.; Camargo, F. A. O.; Okeke, B. C., (2010). Characterization of copper bioreduction and biosorption by a highly copper resistant bacterium isolated from copper-contaminated vineyard soil. Sci. Total Environ., 408 (1), 1501-1507 (7 pages).

APHA; AWWA; WEF, (1992). Standard methods for the examination of water and wastewater. 18th edition. American Public Health Association, American Water Works Association and the Water Environment Federation. Washington DC., USA.

Barker, L. P.; Brooks, D. M.; Small, P. L. C., (1998). The identification of Mycobacterium marinum genes differentially expressed in macrophage phagosomes using promoter fusions to green fluorescent protein. Molecular Microbiol., 29 (5), 1167-1177 (11 pages).

Barros, F. C. F.; Sousa, F. W.; Cavalcante, R. M.; Carvalho, T. V.; Dias, F. S.;Queiroz, D. C.; Vasconcellos, L. C. G.; Nascimento, R. F., (2008). Removal of copper, nickel and zinc ions from aqueous solution by chitosan-8hydroxyquinoline beads. Clean., 36 (3), 292- 298 (7 pages).

Casper, S.; Holt, C., (1996). Expression of the green fluorescent protein-encoding gene from a tobacco mosaic virus-based vector. Gene., 173 (1), 69-73 (5 pages).

Cassidy, M. B.; Leung, K. T.; Lee, H.; Trevors, J. T., (2000). A comparison of enumeration methods for culturable Pseudomonas fluorescens cells marked with green fluorescent protein. J. Microbiol. Mtds., 40 (2), 135-145 (11 pages).

Chakraborty, P.; Babu, G.; Alam, A.; Chaudhari, A., (2008). GFP expressing bacterial biosensor to measure lead contamination in aquatic environment. Curr. Sci., 94 (6), 800-805 (6 pages).

Chalfie, M.; Tu, Y.; Euskirchen, G.; Ward, W. W.; Prasher, D. C., (1994). Green fluorescent protein as marker for gene expression. Sci., 263 (5148), 802-805 (4 pages).

Chien, M. K.; Shih, L. H., (2007). An empirical study of the implementation of green supply chain management practices in the electrical and electronic industry and their relation to organizational performances. Int. J. Environ. Sci. Tech., 4 (3), 383-394 (12 pages).

D’Souza, S. F., (2001). Microbial biosensors. Biosen. Bioelec., 16 (6), 337-353 (17 pages).

Edward Raja, C.; Selvam, G. S., (2009). Plasmid profile and curing analysis of Pseudomonas aeruginosa as metal resistant. Int. J. Environ. Sci. Tech., 6 (2), 259-266 (8 pages).

Giaginis, C.; Gatzidou, E.; Theocharis, S., (2006). DNA repair systems as targets of cadmium toxicity. Toxicol. Appl. Pharmacol., 213 (3), 282-290 (9 pages).

Gronow, M., (1984). Biosensors. Trends Biochem. Sci., 9 (8), 336-340 (5 pages).

Gu, M. B.; Mitchell, R. J.; Kim, B. C., (2004). Whole-cell-based biosensors for environmental biomonitoring and application. Adv. Biochem. Eng . Biotech., 87, 269-305 (37 pages).

Gueu, S.; Yao, B.; Adouby, K.; Ado, G., (2007). Kinetics and thermodynamics study of lead adsorption on to activated carbons from coconut and seed hull of the palm tree. Int. J. Environ. Sci. Tech., 4 (1), 11-17 (7 pages).

Il'yasova, D.; Schwartz, G. G., (2005). Cadmium and renal cancer. Toxicol. Appl. Pharmacol., 207 (2), 179-186 (8 pages).

Ivask, A.; Hakkila, K.; Virta, M., (2001). Detection of organomercurials with sensor bacteria. Analys. Chem., 73 (21), 5168-5171 (4 pages).

Karbassi, A. R.; Nouri, J.; Mehrdadi, N.; Ayaz, G. O., (2008). 
Flocculation of heavy metals during mixing of freshwater with Caspian Sea water. Environ. Geo., 53 (8), 1811-1816 (6 pages).

Kopera, E.; Schwerdtle, T.; Hartwig, A.; Bal, W., (2004). Co (II) and Cd (II) substitute for $\mathrm{Zn}$ (II) in the zincfinger derived from the DNA repair protein XPA, demonstrating a variety of potential mechanisms of toxicity. Chem. Res. Toxicol., 17 (11), 1452-1458 (7 pages).

Laemmli, U. K., (1970). Cleavage of structural proteins during the assembly of the head of bacteriophage $T_{4}$. Nature, 227, 680-685 (6 pages).

Liao, V. H. C.; Chien, M. T.; Tseng, Y. T.; Ou, K. L., (2006). Assessment of heavy metal bioavailability in contaminated sediments and soils using green fluorescent protein based bacterial biosensors. Environ. Poll., 142 (1), 17-23 (7 pages).

Liu, J.; Olsson, G.; Mattiasson, B., (2004). Short-term BOD (BODst) as a parameter for on-line monitoring of biological treatment process Part I. A novel design of BOD biosensor for easy renewal of bio-receptor. Biosen. Bioelect., 20 (3), $562-570$ ( 9 pages).

Ludin, B.; Doll, T.; Meill, R.; Kaech, S.; Matus, A., (1996). Application of novel vectors for GFP-tagging of proteins to study microtubule-associated proteins. Gene., 173 (1), $107-$ 111 (5 pages).

Malakootian, M.; Nouri, J.; Hossaini, H., (2009). Removal of heavy metals from paint industries wastewater using Leca as an available adsorbent. Int. J. Environ. Sci. Tech., 6 (2), 183190 (8 pages).

Moss, J. B.; Price, A. L.; Raz, E.; Driever, W.; Rosenthal, N., (1996). Green fluorescent protein marks skeletal muscle in murine cell lines and zebrafish. Gene., 173 (1), 89-98 (10 pages)

Mulchandani, A.; Bassi, A. S., (1995). Principles and application of biosensors for bioprocess monitoring and control. Crit. Rev. Biotech., 15 (2), 105-124 (20 pages).

Niedenthal, R. K.; Riles, L.; Johnston, M.; Hegemann, J. H., (1996). Green fluorescent protein as a marker for gene expression and subcellular localization in budding yeast. Yeast., 12 (8), 773-786 (14 pages).

Nouri, J.; Khorasani, N.; Lorestani, B.; Karami ; M. Hassani ; Hassani, A. H.; Yousefi, N., (2009). Accumulation of heavy metals in soil and uptake by plant species with phytoremediation potential. Environ. Earth Sci., 59 (2); 315 323 ( 9 pages)

Nouri, J.; Lorestani, B.; Yousefi, N.; Khorasani, N.; Hasani, A. H.; Seif, S.; Cheraghi, M., (2011). Phytoremediation potential of native plants grown in the vicinity of Ahangaran leadzinc mine (Hamedan, Iran). Environ. Earth Sci., 62 (3), 639644 (6 pages).

Prachayasittikul, V.; Isarankura Na Ayudhaya, C.; Bulow, L.,
(2001). Lighting E. coli cells as biological sensors for Cd. Biotech. Let., 23 (16), 1285-1291 (7 pages).

Roberto, F.; Barnes, J.; Bruhn, D., (2002). Evaluation of a GFP reporter gene construct for environmental arsenic detection. Talanta, 58 (1), 181-188 (8 pages).

Samarghandi, M. R.; Nouri, J.; Mesdaghinia, A. R.; Mahvi, A. H.; Nasseri, S.; Vaezi, F., (2007). Efficiency removal of phenol, lead and cadmium by means of $\mathrm{UV} / \mathrm{TiO}_{2} / \mathrm{H}_{2} \mathrm{O}_{2}$ processes. Int. J. Environ. Sci. Tech., 4 (1), 19-25 (7 pages).

Sambrook, J.; Fritsch, E. F.; Maniatis, T., (1989). Molecular Cloning: A laboratory manual, $2^{\text {nd }} E d$. Cold spring harbour, NY: Cold spring harbour laboratory press.

Selifonova, O.; Burlage, R.; Barkay, T., (1993). Bioluminescent sensors for detection of bioavailable $\mathrm{Hg}$ (II) in the environment. Appl. Environ. Microbiol., 59 (9), 3083-3090 (8 pages).

Shetty, R.; Ramanathan, S.; Badr, I.; Wolford, J.; Daunert, S., (1999). Green fluorescent protein in the design of a living biosensing system for L-arabinose. Analys. Chem., 71 (4), 763-768 (6 pages).

Shetty, R. S.; Deo, S. K.; Shah, P.; Sun, P.; Rosen, B. P.; Daunert, S., (2003). Luminescence based whole cell sensing systems for cadmium and lead using genetically engineered bacteria. Analys. Bioanalys. Chem., 376 (1), 11-17 (7 pages).

Stiner, L.; Halverson, L. J., (2002). Development and characterization of a green fluorescent protein based bacterial biosensor for bioavailable toluene and related compounds. Appl. Environ. Microbiol., 68 (4), 1962-1971 (10 pages).

Tauriainen, S.; Karp, M.; Chang, W.; Virta, M., (1998). Luminescent bacterial sensor for cadmium and lead. Biosen. Bioelect., 13 (9), 931-938 (8 pages).

Townsend, A. T.; Miller, K. A.; Mclean, S.; Aldous, S., (1998). The determination of copper, zinc, cadmium and lead in urine by high resolution inductively coupled plasma mass spectrometry. J. Analys. Atom. Spect., 13, 1213-1219 (7 pages).

Vandeer meer, J. R.; Tropel, D.; Jaspers, M., (2004). Illuminating the detection chain of bacterial bioreporters. Environ. Microbiol., 6 (10), 1005-1020 (16 pages).

Wang, S.; Hazelrigg, T., (1994). Implications for bcd mRNA localization from spatial distribution of exu protein in Drosophila oogenesis. Nature, 69, 400-403 (4 pages).

Willardson, M. B. B.; Wilkins, F. J.; Rand, A. T.; Schupp, M. J.; Hill, K. K.; Keim, P.; Jackson, J. P., (1998). Development and testing of a bacterial biosensor for toluene based environmental contaminants. Appl. Environ. Microbiol., 64 (3), 1006-1012 (7 pages).

Yagi, K., (2007). Application of whole cell bacterial sensors in biotechnology and environmental science. Appl. Microbiol. Biotech., 73 (6), 1251-1258 (8 pages).

\section{AUTHOR (S) BIOSKETCHES}

Edward Raja, C., M.Sc., Ph.D., Department of Biochemistry, Centre for Excellence in Genomic Sciences, School of Biological Sciences, Madurai Kamaraj University, Madurai-625 021, India. Email: edwardrajac@gmail.com

Selvam, G. S., M.Sc., M. Phil., Ph.D., Full professor, Department of Biochemistry, Centre for Excellence in Genomic Sciences, School of Biological Sciences, Madurai Kamaraj University, Madurai-625 021, India. Email: drselvamgsbiochem@rediffmail.com 